Article

\title{
Do Corporate Social Responsibility Activities Reduce Credit Risk? Short and Long-Term Perspectives
}

\author{
Thuy Thi Thu Truong(i) and Jungmu Kim *(D) \\ Department of Business Administration, School of Business, Yeungnam University, Gyeongsan 38541, Korea; \\ thuytruong@ynu.ac.kr \\ * Correspondence: jungmu@yu.ac.kr; Tel.: +82-53-810-2843
}

Received: 16 October 2019; Accepted: 3 December 2019; Published: 6 December 2019

\begin{abstract}
This study examines the short- and long-run effects of corporate social responsibility (CSR) activities on the credit risk implied in credit derivative prices. Measuring the different term effects on credit risk by the slope of credit default swap (CDS) spreads with different maturities, we investigate how CSR activities affect credit risk differently in the short and long run. Fama-MacBeth regressions reveal that firms with higher CSR scores tend to have more gently decreasing CDS slopes because, on average, CSR activities reduce credit risk in the long run more than in the short run. An analysis of individual CSR categories shows that while community, diversity and employee relations lead to a lower CDS slope, human rights and product characteristics increase the CDS slope. This finding suggests that not all CSR activities affect short-term and long-term credit risks in the same direction. Therefore, even though CSR activities can reduce credit risk in the long-run, some CSR activities may increase the short-term credit risk and hence increase short-term borrowing costs.
\end{abstract}

Keywords: CDS spreads; CDS term structure; corporate social responsibility; credit risk; cost of capital

\section{Introduction}

Do corporate social responsibility (CSR) activities affect the term-structure of credit spreads? If it is the case, which spread is more sensitive to CSR, short-term or long-term? While a number of studies have shown that CSR reduces credit risk and corporate spreads, little is known about the effect on the term-structure. We conjecture that CSR activities are more influential on long-term credit spreads because the effect of CSR is mostly related to the level of future cash flows (or firm values) and the uncertainty of future cash flows, which are more significant for long-term spreads. Therefore, we expect that on average, firms with higher CSR activities have smaller differences between long-term and short-term credit spreads.

The debate on corporate social responsibility (CSR) begin in the early twentieth century. CSR has recently played an important role in corporate activities both within and outside the United States. Many researchers have recently suggested that firms involved in CSR may develop a positive social responsibility image, thereby enhancing their reputation [1,2]. Hence, firms have made efforts to get involved in CSR activities in many aspects of business to contribute to sustainable development [3].

An increasing number of studies have analyzed the effect of CSR on financial performance [4-7], firm risk [8,9], or cost of capital [2,10-12]. In terms of firm risk, some studies explored the effect of CSR on credit risk (i.e., a company's ability to meet its financial obligations). Most previous researchers have demonstrated that CSR activities can help reduce the probability of default or credit risk. Sun and Cui [13] use the Standard and Poor's corporate credit rating as a measure of firm credit risk and report that CSR helps firms reduce the credit risk. Attig et al. [14] suggest that in the valuation of firms' creditworthiness, rating agencies give high ratings to firms that engage in good CSR activities. The impact of CSR on bond ratings and corporate bond spreads has been investigated by Oikonomou et 
al. [15]. They find lower spreads and better ratings for firms with CSR strengths, while higher spreads and lower ratings for firms with CSR weaknesses. Jiraporn et al. [16] also find that higher CSR levels lead to better credit ratings. These studies measure credit risk in terms of bond yields or credit ratings. However, the credit default swap (CDS) spread is considered a better measure of credit risk than bond yields for many reasons [17]. Han and Zhou [18] also suggest that CDS spreads have various advantages over alternative measures of credit risk. Therefore, CDS has become increasingly popular as a more reliable proxy for corporate credit risk.

The relationship between CSR activities and credit risk has been explored, but previous studies have never paid attention to the topic in a view of term-structure. An investment in CSR activities may induce insolvency of a company, and raise short-term credit risk even if such activities can reduce its credit risk in the long-run. Therefore, the effect of CSR activities can be different for different terms. In addition, the term effect leads to the term-structure of cost of capital; short-term borrowing is more costly than long-term borrowing if the short-term credit risk is higher. Based on this intuition, we examine if the CSR activities affect the credit risk differently for different terms. Also, we explore the market participants' expectation about how CSR activities affect short- and long-term credit risks. If overall CSR activities affect the term-structure, going one step further, we examine what kind of CSR activities affect short-term credit risk and/or long-term credit risk. Depending on the type of CSR, the effect can be different.

To evaluate the market expectation, we employ CDS data. CDS is a swap contract in which the buyer pays the seller premium until the assets default or the maturity date is reached. If the underlying financial instrument defaults, the buyer receives a payoff. The buyer's protection payment for the covered period is called the CDS spread. CDS spreads theoretically represent the required amount of compensation when taking on the pure credit risk of a reference security. Barth et al. [19] use CDS spreads as a measure of credit risk. They examine the relationship between CSR and CDS spreads. They find that better CSR scores seem related to lower CDS spreads, that is, less credit risk. Previous studies indicate that investing in CSR reduces credit risk. However, whether a firm that invests in CSR can reduce the probability of default more strongly in the short or long term has not been studied. To the best of our knowledge, the relationship between CSR and term-structure of credit spreads remains unexplored. Thus, CDS data is employed to measure the slope of credit spreads. This approach is better than using corporate bond data. The maturities of the CDS contracts can be compared between companies and are fixed over time. By contrast, the maturity of bonds is not consistent across companies and changes greatly over time [18,20].

The slope of CDS spreads implicates the investors' perception of the future credit risk. Upward-sloping CDS spreads is likely to indicate that investors expect the possible decrease in the firm's credit quality and the increase in CDS spreads over the longer term. Therefore, the slope of CDS spreads, as an indicator of a firm's future creditworthiness, need to be deeply investigated. This study examines whether investors perceive CSR activities to affect CDS spreads more in the short or long term. Studying the relationship between CSR and the slope of CDS spreads helps managers understand how investing in CSR activities affects the probability of default over different time horizons and thus, have important implication on corporate decisions.

Our methodology and main findings are summarized as follows. First, we examine the relation between the overall CSR score and the credit-term structure, using Fama-MacBeth regressions [21]. We use the difference between the five-year and one-year CDS spreads as proxy for the slope of CDS spreads. We also use alternative measures of the CDS slope, such as the difference between the ten-year and one-year CDS spreads. The main results have not changed. The empirical results suggest that investing in more CSR activities makes the CDS slope lower because CSR reduces CDS spreads in the long term more than in the short term. This is indicated when we examine the effect of CSR on levels of CDS spreads, both in the long term (defined by five-year or ten-year CDS spreads) and the short term (defined by one-year CDS spreads). 
Second, we examine the effect of the individual components of CSR activities, including community, human rights, employee relations, environment, diversity, and product characteristics on the credit-term structure. The results, based on Fama-MacBeth regressions, reveal that out of the six components, three are negatively related to the CDS slope, one is not likely to relate to the CDS slope and two are positively related to the CDS slope. Specifically, better scores of community, diversity and employee relations are associated with a lower CDS slope and significant at the $1 \%$ level. We determine the reason by examining the relationship between the individual components of CSR activities and the levels of CDS spreads in the long and short terms. Community, diversity and employee relations reduce the long-term CDS spreads (i.e., less credit risk) more than the short-term CDS spreads. We find that environment activities reduce CDS spreads both in the long and short terms, but the longand short-term CDS spreads are not significantly different. Interestingly, the dimensions of CSR activities that increase the difference between long- and short-term CDS spreads are the product characteristics and human rights. Firms that invest in product characteristics and human rights increase their long-term credit risk more than short-term credit risk.

The remainder of this study is structured as follows. Section 2 reviews theoretical background of CSR and its effect on many aspects, such as firm value and volatility of future cash flow, thereby affecting long-term and short-term credit risk (i.e., term-structure of credit spreads). Section 3 describes data on the level and slope of CDS spreads, CSR, and other control variables such as leverage ratio, volatility, return on assets, and CDS liquidity. The methodology is detailed in Section 4 . The results are interpreted and discussed in Section 5. Finally, conclusions and shortcomings are provided in Section 6.

\section{Theoretical Background and Hypotheses}

We conjecture that CSR activities are more influential on long-term credit spreads because the effect of CSR is mostly related to the level of future cash flows (or firm values) and the uncertainty of future cash flows, which are more significant for long-term spreads. Therefore, we expect that on average, firms with higher CSR activities have smaller differences between long-term and short-term credit spreads. Merton [22], which is the most frequently cited literature on credit risk, suggests a structural model that explains the determinants of corporate default risk. The Merton model finds that default probability is negatively associated with (present) firm value and positively associated with volatility of firm value. Many empirical studies [17,23-25] have supported this prediction. Therefore, we need to examine how CSR activities affect the credit risks via the two channels: (i) the current value of a firm and (ii) the volatility (or uncertainty) of future firm values.

First, a large number of studies have shown that the CSR can enhance firm values through a mediator such as customer satisfaction [26] and consumer preference [2,27], which increases business performance (or cash flows). For example, Luo and Bhattacharya [26] discuss that CSR would lead to more customer satisfaction. Indeed, socially responsible companies are distinguished from their competitors and thus CSR-related activities positively influence customers' attitude towards the company $[2,27]$. Customers are willing to identify themselves with firms that tend to trust and easily forgive firms' mistakes $[28,29]$. Hence, the more a firm is socially responsible, the more motivated the customer will be to identify and support the firm [30]. Besides, CSR is linked with financial performance, including three determinants: financial performance, employee commitment, and corporate reputation $[6,31,32]$. These factors affect the present value of a firm, but very marginally. The results of customer satisfaction will be realized in terms of financial performance in the future, and it increases future cash flows in the long-run rather than in the short-run. The present value is also affected by the future cash flows, but they are highly discounted in the present value framework [33]. Therefore, the short-term effect of CSR via this channel is rather marginal. Instead, the long-term effect is relatively strong because future profitability leads to future cash flows which significantly increase future value of a firm. Thus, although CSR activities enhancing firm values can affect both the short-term and long-term credit spreads, long-term credit spreads are more sensitive to CSR investment. 
Second, CSR-related activities may reduce the volatility of firm value by enhancing a firm's sociable image [34,35], increasing customer loyalty and attracting high-quality employees [36,37], and providing a signal of efficient use of resources [38,39]. A good image with corporate social responsibility will reduce a negative impact as well as punishment of external shareholders and consumers when negative events occur. Thereby, CSR firms can stabilize their future cash flows or firm values and prevent the firm from falling into default $[34,35]$. Furthermore, good CSR reputation can enhance relations with firm stakeholders such as increasing customer loyalty, attracting high-quality employees [36,37]. Therefore, building good relations with stakeholders may reduce future uncertainty, especially to improve long-term sustainability and reduce long-term the probability of default. Furthermore, scholars argue that investments in CSR are likely to be financed by internal resources $[38,39]$. Hence, investing in CSR is considered as a signal of an efficient allocation of internal resources, this may in turn increase the firm's credit rating. Jiraporn et al. [16] find that firms invest in more CSR activities get more favorable credit ratings. Attig et al. [14] also find that social activities is positively related to firms' credit ratings. Specifically, they find that diversity, employee relations, community, product characteristics, and environment are the attributes that explain firms' creditworthiness. In general, they argue that rating agencies may see positive CSR activities to be beneficial in their ranking decisions because long-term sustainable improvements reduce the probability of default.

Previous studies have provided empirical evidence that CSR activities decrease firm risk, which in turn reduce firm's credit risk. For instance, Lee and Faff [8] suggest that firms with high corporate social performance reduce idiosyncratic risk significantly. Jo and Na [40] analyze U.S. companies during the 1991 to 2010 period and find that CSR activities inversely affect firm risk in controversial industry sectors. Bouslah et al. [41] prove that individual dimensions of CSR have different effects on firm risk over the period from 1991 to 2007. Specifically with regard to credit risk, Chang et al. [42] show that companies with good CSR reduce their short-term and forward default probability. Using the credit ratings of 303 companies from Standard and Poor's during the period from 2008 to 2010, Sun and Cui [13] find that CSR helped corporations reduce their default risk in the 2008/2009 financial crisis, and this effect was stronger for corporations in highly dynamic environments.

An impact on uncertainty of future firm values causes a change in discount rate within the present value framework [33]. The effect of discount rate changes is much more significant for long-term cash flows. Therefore, the CSR activities that enhance the sustainability of a firm's profitability have more impact on the long-term credit risk than the short-term credit risk.

So far, we have discussed the two channels through which CSR may affect the short-term and long-term credit spreads with a different magnitude, and hence affect the term-structure of credit spreads. Intuitively, investing in CSR-related activities may increase costs. There are CSR activities that cannot be profitable for a short term. If the firm does not allocate investments appropriately, it could easily lead to short-term credit risk. Conversely, the CSR activities that enhance firm's reputation may attract consumers' attention, thus increasing firm sales, firm value and reducing short-term credit risk. In long-term perspective, CSR activities can generate long-term profits through building good relations with stakeholders, thereby reducing credit risk in long term. In summary, CSR activities may affect credit risk through firm value and volatility of future firm value. However, this effect may be different in the short- and long-terms.

The development of our hypotheses can be summarized in Figure 1. The option pricing theory by Merton [22] and Black and Scholes (BS) [43] can provide a good explanation about the reason why the uncertainty of future firm values has a stronger impact on the long-term credit risk while the firm value equally affects the short-term and long-term credit risk. As shown in Friewald et al. [44], CDS spread can be seen as a put option on the firm value. Therefore, the BS option vega measures the effect of the uncertainty change on the credit spread. Denoting uncertainty by $\sigma$, firm value by $V$, maturity of debt by $T$, and the amount of debt obligation by $D$, the BS put option vega is given by

$$
\text { vega }=\frac{\partial \mathrm{CDS}}{\partial \sigma}=V \sqrt{T} \phi(d)
$$


where $\phi$ is the standard normal density function, $d=\frac{\ln \left(\frac{V}{D}\right)+\left(r+\sigma^{2}\right) T}{\sigma \sqrt{T}}$ and $r$ is the risk-free rate. Differentiating Equation (1) with respect to maturity $T$ reveals the different effect of uncertainty on the short-term and long-term credit risks. That is,

$$
\text { veta }=\frac{\partial \text { vega }}{\partial T}=\frac{\partial^{2} \mathrm{CDS}}{\partial T \partial \sigma}=-V \phi(d) \sqrt{T}\left[\frac{r d}{\sigma \sqrt{T}}-\frac{1+d(d-\sigma \sqrt{T})}{2 T}\right]
$$

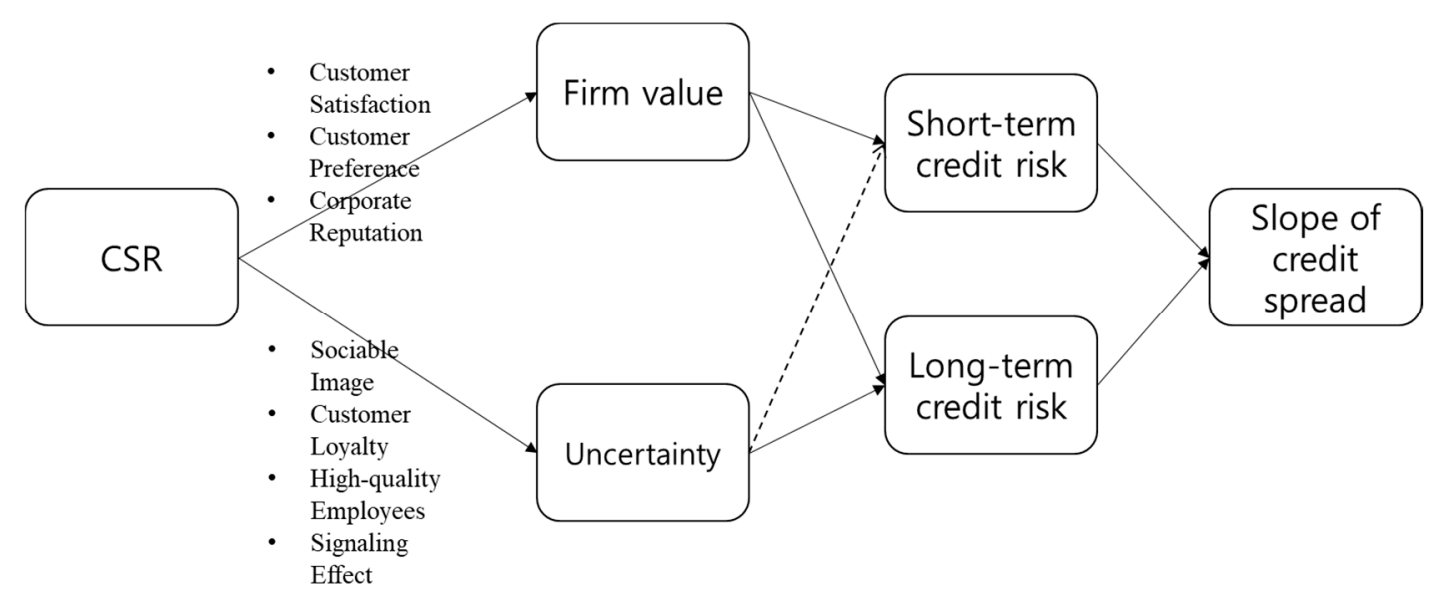

Figure 1. Hypothesis development.

Thus, if the veta value is positive, the effect of $\sigma$ is larger for long-term spreads. The Equation (2) can be either positive or negative, but within a reasonable region of parameters the veta is positive. Given a leverage ratio $\frac{D}{V}=0.5$, maturity $T=1$, and the risk-free rate $r=0.05$, Figure 2 shows the simulation result for various uncertainty levels from 0.1 to 0.5 . All these inputs are taken in consideration of the reality of the US data. The simulation confirms that the effect of uncertainty is more significant for long-term maturity spreads.

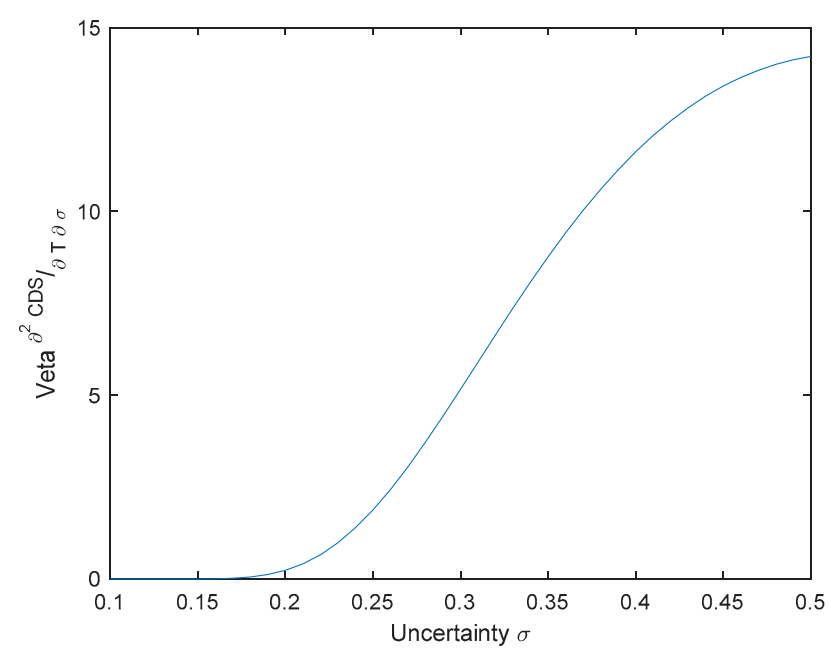

Figure 2. Credit default swap (CDS) veta for various levels of uncertainty.

Based on this theoretical background, we hypothesize:

Hypothesis 1. Overall CSR activities differently affect the short-term and long-term credit risks; long-term $C D S$ spreads are more influenced by overall CSR activities. 
Hypothesis 2. The type of CSR activities differently affect the credit risk. While some categories of CSR activities may increase or decrease credit risk.

From Hypotheses 1 and 2, we also conjecture that while CSR activities reducing credit risk would reduce the long-term CDS spreads more significantly, CSR activities raising credit risk would increase the long-term CDS spreads more significantly.

\section{Data}

\subsection{The Slope of Credit Default Swaps}

We obtain CDS data from Markit. Based on the availability of CSR data, our sample period is from January 2001 to December 2013. We include the U.S. dollar-denominated CDS contracts of US corporates. Moreover, we exclude firms that are in the utilities and financial sectors. For the purpose of estimation, we also exclude firms that have missing values for the CDS spreads of one-year, five-year, and ten-year maturities. The slope of the CDS spreads are measured by the five-year minus one-year CDS spreads (expressed in basis points). We also employ alternatives to the CDS slope, such as the difference between the ten-year and one-year CDS spreads and the results do not change qualitatively. After filtering data and combining CDS data with CSR data and accounting information (the detailed descriptions are shown below), our sample data has 507 firms with 45,375 firm-month observations.

\subsection{Corporate Social Responsibility}

We define CSR score as in previous studies [11,45] and obtain data from MSCI ESG STATS. MSCI ESG is an independent firm that provides analysis, and consulting services on environmental and social practices to corporations interested in making socially responsible decisions. Specifically, we use KLD ratings for each of the main CSR categories: community, product characteristics, employee relations, human rights, diversity, and the environment. As mentioned in previous studies [11,14], we also exclude corporate governance. A set of concerns and strengths for each qualitative issue area is assigned a binary (0/1) rating, as detailed in El Ghoul et al. [11]. In other words, KLD assigns a rating of " 1 " if the firm meets the required criteria to merit either an evaluation of "strength" or "concern" for each category. Otherwise, KLD assigns a rating of " 0. " In line with these studies, we calculate the score by the number of concerns minus the number of strengths, for each firm-year in each category. We then sum up the scores of all CSR categories to get the overall CSR scores.

\subsection{Control Variables}

The control variables in the regression model, computed at the end of month $t$, are constructed as follows:

- Leverage (LEV): Leverage ratio is defined as follows:

$$
\frac{D+P E}{D+P E+E}
$$

where $E$ is the market value of the equity (the number of shares outstanding multiplied by current price of stock). $D$ is the sum of the book values of long-term and current liabilities, and $P E$ is the book value of the preferred equity. To estimate monthly leverage ratios, we linearly interpolate quarterly values $[17,23]$. Han and Zhou [18] prove that the higher the firm's leverage, the higher the CDS spread for long- or short-term contracts. This impact is stronger for those with longer maturity. Hence, a positive relationship between leverage and the CDS slope is expected.

- Volatility (IV or HV): We use the implied volatility (IV) of at-the-money put options with a maturity of 30 days, which is collected from OptionMetrics [18], as a proxy for the expected stock volatility. We also use the annualized standard deviation of returns in the previous 250 trading days as the 
historical volatility (HV) [17]. Daily stock returns are collected from the Center for Research in Security prices (CRSP). Han and Zhou [18] prove that a higher volatility increases the CDS level (i.e., the probability of default), with stronger effect for CDS contract with longer maturity. Thus, we expect a positive relationship between stock volatility and the slope of CDS spreads.

- Level of CDS spreads (CDS): The level of CDS spreads may affect the slope of CDS spreads. We use the level of five-year CDS spread as a control variable because a five-year CDS spread is more liquid than other maturities.

We also control for the following variables. Although previous studies have shown that these variables are associated with the level of CDS spreads, it is unclear whether their impact is stronger on CDS in short-run or long-run.

- Return on Assets (ROA): We calculate monthly return on assets as income before extraordinary items divided by the previous quarter's total assets, as provided by COMPUSTAT. Income is taken from the most recent quarter that reported before the end of month $t$.

- CDS liquidity (DEPTH): The liquidity of the CDS may affect the spread values. Following some papers [46,47], the depth is also used to measure CDS liquidity. Depth is the number of contributors that build spreads daily obtained from Markit data.

\section{Methodology}

Our study investigates the short- and long-run impacts of CSR activities on the credit risk implied in credit derivative prices. We estimate different Fama-MacBeth regressions by running monthly cross-sectional regressions to obtain a time-series of coefficient values. Then, the reported coefficients are calculated as the time-series average of estimated values.

We run cross-sectional regressions of the individual slopes of CDS spreads, which are calculated by five-year CDS spreads (or ten-year CDS spreads) minus one-year CDS spreads at month $t$, on CSR scores at month $t$. Because CSR scores are available with annual frequency, we assign the CSR score at the end of year $t$ for the CSR score from January of year $t$ to December of year $t$ to obtain monthly observations. As suggested by a previous study [18], we control for the effects of other determinants of the CDS slope, namely, leverage effect and volatility effect. We also control for the level of CDS spread, ROA, and CDS liquidity. Control variables are all calculated at month $t$. The control variables are described in detail in Section 3. The coefficients on CSR scores in our regressions should indicate the relation between CSR and the slope of CDS spreads that is not captured by our control variables.

We also examine the relationship between the slope of CDS spreads and the individual categories of the CSR activities by replacing the overall CSR score with the CSR scores of six categories: community, product characteristics, environment, human rights, employee relations, and diversity. The regressions repeat the same procedure used in the case above.

We base our t-statistics on the Newey and West [48] standard errors of coefficients with 12 lags. At the $1 \%$ and $99 \%$ levels, all independent variables are winsorized for each period to minimize the effect of outliers in the data.

\section{Empirical Results}

\subsection{Summary Statistics}

Panel A of Table 1 shows the descriptive statistics for the levels of CDS spreads with one-, two-, three-, five-, seven-, and 10-year maturities and the slope of CDS spreads measured by the difference between the five-year and one-year CDS spreads (Slope_51) or the difference between the 10-year and one-year CDS spreads (Slope_101). All the spread levels and slope are in basis points. The average value of the CDS spreads increases with the length of maturity, suggesting upward-sloping CDS spreads. During the sample period, the average values are 97.43 basis points (bps) for the one-year CDS spreads, $175.41 \mathrm{bps}$ for the five-year CDS spreads and $197.19 \mathrm{bps}$ for the 10 -year CDS spreads. The 
average slope is positive, confirming the upward slope of the CDS spreads. Across the whole sample, the average of the CDS slope measured by the five-year CDS spreads minus the one-year CDS spreads (10-year minus 1-year) is $77.98 \mathrm{bps}$ ( $99.77 \mathrm{bps}$ ) and the standard deviation is $894.60 \mathrm{bps}$ ( $846.76 \mathrm{bps})$.

Table 1. Summary statistics.

\begin{tabular}{|c|c|c|c|c|c|c|c|}
\hline \multicolumn{8}{|c|}{ Panel A: Descriptive Statistics for Levels of CDS Spreads and CDS Slope } \\
\hline & \multicolumn{2}{|c|}{ Mean } & \multicolumn{2}{|c|}{ Standard Deviation } & \multicolumn{2}{|c|}{ Min } & Max \\
\hline 1-year & \multicolumn{2}{|c|}{97.43} & \multicolumn{2}{|c|}{128.95} & \multicolumn{2}{|c|}{4.33} & 1081.19 \\
\hline 2-year & \multicolumn{2}{|c|}{118.25} & \multicolumn{2}{|c|}{146.89} & \multicolumn{2}{|c|}{6.89} & 1153.13 \\
\hline 3-year & \multicolumn{2}{|c|}{138.90} & \multicolumn{2}{|c|}{158.80} & \multicolumn{2}{|c|}{9.80} & 1270.42 \\
\hline 5 -year & \multicolumn{2}{|c|}{175.41} & \multicolumn{2}{|c|}{180.19} & \multicolumn{2}{|c|}{15.98} & 1445.71 \\
\hline 7-year & \multicolumn{2}{|c|}{188.13} & \multicolumn{2}{|c|}{181.83} & \multicolumn{2}{|c|}{20.06} & 1472.75 \\
\hline 10-year & \multicolumn{2}{|c|}{197.19} & \multicolumn{2}{|c|}{178.39} & \multicolumn{2}{|c|}{23.05} & 1397.87 \\
\hline Slope_51 & \multicolumn{2}{|c|}{77.98} & \multicolumn{2}{|c|}{93.11} & \multicolumn{2}{|c|}{-273.38} & 894.60 \\
\hline Slope_101 & \multicolumn{2}{|c|}{99.77} & \multicolumn{2}{|c|}{104.46} & \multicolumn{2}{|c|}{-411.17} & 846.76 \\
\hline \multicolumn{8}{|c|}{ Panel B: Correlation Matrix } \\
\hline & CDS & CSR & LEV & HV & IV & ROA & DEPTH \\
\hline CDS & 1 & & & & & & \\
\hline CSR & $-0.216^{* * *}$ & 1 & & & & & \\
\hline LEV & $0.456^{* * *}$ & $-0.198^{* * *}$ & 1 & & & & \\
\hline $\mathrm{HV}$ & $0.623 * * *$ & $-0.166^{* * *}$ & $0.286^{* * *}$ & 1 & & & \\
\hline IV & $0.553^{* * *}$ & $-0.077^{* *}$ & $0.263^{* * *}$ & $0.683^{* * *}$ & 1 & & \\
\hline ROA & $-0.438^{* * *}$ & $0.134^{* * *}$ & $-0.491^{* * *}$ & $-0.323^{* * *}$ & $-0.328^{* * *}$ & 1 & \\
\hline DEPTH & $-0.112 * * *$ & $0.040^{* * *}$ & $0.069^{* * *}$ & $-0.069^{* * *}$ & $-0.063^{* * *}$ & -0.03 & 1 \\
\hline
\end{tabular}

The time variation in the slopes of CDS spreads is illustrated in Figure 3, plotting the monthly time-series of the cross-section of individual firms' CDS slope measured by the difference between the five-year and the one-year CDS spreads (Slope_51) or the difference between 10-year and the one-year CDS spreads (Slope_101). Most of the time, the slope of the CDS spreads is positive. This confirms the upward slope of CDS spreads. The slope is negative in late 2002, early 2003, and early 2009 , which indicates that the term-structure of CDS spreads is downward sloping.

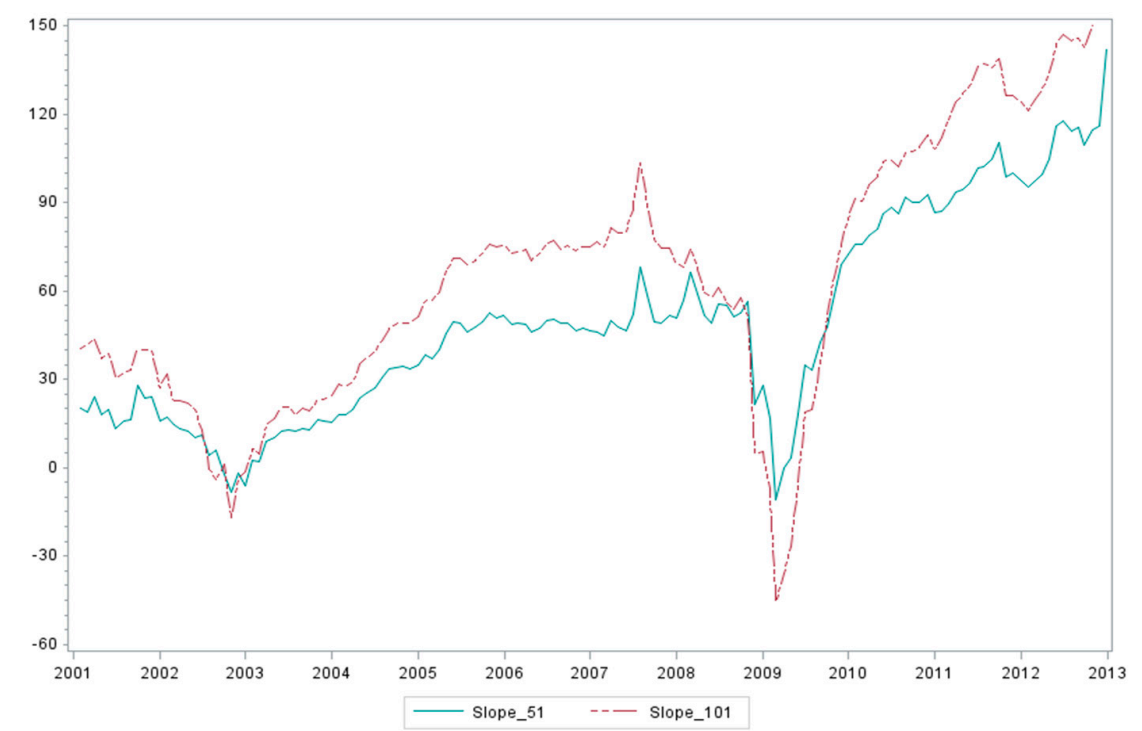

Figure 3. Time series of the slope of CDS spreads. 
Panel B of Table 1 shows the correlation between CSR and other control variables including the five-year CDS spread (CDS), option-implied volatility (IV), historical volatility (HV), leverage ratio (LEV), return on assets (ROA), and CDS liquidity (DEPTH). The reported values are time-series average of the correlations. As shown in the table, CSR is negatively correlated with the five-year CDS spread, leverage, historical volatility, and option-implied volatility, but it is positively correlated with return on assets and CDS liquidity. However, the magnitudes of their correlation are small (lower than 0.2), suggesting that CSR captures different information from the other determinants of the CDS slope. The two volatility measures (historical volatility and option-implied volatility) are positively correlated (corr $=0.683$ ). Thus, we control each volatility measure in each model.

Table 2 reports the descriptive statistics of CSR scores over the sample period. The CSR ranges from a minimum of -9 to a maximum of 18 . The average of the CSR scores for 2013 is higher than those for the previous years. This suggests that in 2013, firms have focused on CSR strength in six areas: community, human rights, environment, employee relations, diversity, and product characteristics.

Table 2. Descriptive statistics of corporate social responsibility (CSR) scores.

\begin{tabular}{ccccc}
\hline Year & Mean & Min & Max & SD \\
\hline 2001 & 0.32 & -9 & 9 & 2.19 \\
\hline 2002 & 0.25 & -9 & 9 & 2.24 \\
\hline 2003 & -0.22 & -9 & 10 & 1.65 \\
\hline 2004 & -0.38 & -8 & 11 & 1.79 \\
\hline 2005 & -0.38 & -8 & 11 & 1.91 \\
\hline 2006 & -0.38 & -8 & 15 & 2.02 \\
\hline 2007 & -0.38 & -9 & 14 & 2.09 \\
\hline 2008 & -0.37 & -9 & 13 & 2.11 \\
\hline 2009 & -0.38 & -9 & 13 & 2.10 \\
\hline 2010 & -0.64 & -7 & 17 & 2.50 \\
\hline 2011 & -0.37 & -7 & 18 & 2.79 \\
\hline 2012 & 0.62 & -5 & 16 & 2.20 \\
\hline 2013 & 1.57 & -7 & 17 & 2.85 \\
\hline
\end{tabular}

\subsection{Fama-MacBeth Regressions}

In this section, the results of the Fama-MacBeth regressions are reported in Table 3 to investigate the effect of CSR on the CDS slope, after simultaneously controlling for other cross-sectional effects. The dependent variable is defined as the slope of CDS spreads measured by the difference between the five-year and one-year CDS spreads (in Panel A) or the difference between the 10-year and one-year CDS spreads (in Panel B). The independent variables include CSR score (CSR), leverage ratio (LEV), option-implied volatility (IV), historical volatility (HV), the five-year CDS spread (CDS), return on

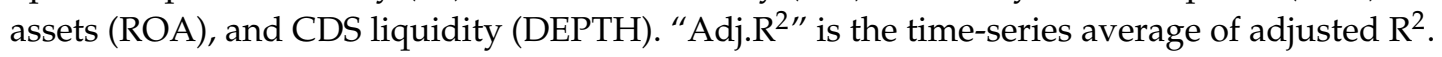


Table 3. Cross-sectional regressions of the slope of CDS spreads on overall CSR scores.

\begin{tabular}{|c|c|c|c|c|c|c|}
\hline Model & I & II & III & IV & V & VI \\
\hline \multicolumn{7}{|c|}{ Panel A: Slope of CDS Spreads Measured by Difference between 5-Year and 1-Year CDS Spreads } \\
\hline Intercept & $\begin{array}{c}33.459 * * * \\
(12.95)\end{array}$ & $\begin{array}{c}29.835^{* * *} \\
(11.29)\end{array}$ & $\begin{array}{c}23.832 * * * \\
(3.73)\end{array}$ & $\begin{array}{c}26.051^{* * *} \\
(7.07)\end{array}$ & $\begin{array}{c}34.096^{* * *} \\
(11.07)\end{array}$ & $\begin{array}{c}26.612^{* * *} \\
(7.95)\end{array}$ \\
\hline CSR & $\begin{array}{c}-0.448^{* * * *} \\
(-4.18)\end{array}$ & $\begin{array}{c}-0.360 * * * \\
(-3.93)\end{array}$ & $\begin{array}{c}-0.436^{* * *} \\
(-4.42)\end{array}$ & $\begin{array}{c}-0.372 * * * \\
(-4.37)\end{array}$ & $\begin{array}{c}-0.192^{* * *} \\
(-3.71)\end{array}$ & $\begin{array}{c}-0.195^{* * *} \\
(-3.88)\end{array}$ \\
\hline LEV & & $\begin{array}{c}0.129 * * * \\
(5.50)\end{array}$ & & & $\begin{array}{l}-0.013 \\
(-1.09)\end{array}$ & $\begin{array}{l}-0.008 \\
(-0.67)\end{array}$ \\
\hline IV & & & $\begin{array}{c}0.265^{* *} \\
(2.05)\end{array}$ & & $\begin{array}{c}-0.225^{* * *} \\
(-3.27)\end{array}$ & \\
\hline $\mathrm{HV}$ & & & & $\begin{array}{c}0.289 * * * \\
(3.35)\end{array}$ & & $\begin{array}{l}0.008 \\
(0.17)\end{array}$ \\
\hline CDS & & & & & $\begin{array}{c}0.071^{* * *} \\
(5.24)\end{array}$ & $\begin{array}{c}0.063^{* * *} \\
(6.28)\end{array}$ \\
\hline $\mathrm{ROA}$ & & & & & $\begin{array}{c}-0.401 \text { *** } \\
(-2.76)\end{array}$ & $\begin{array}{c}-0.431^{* * *} \\
(-2.99)\end{array}$ \\
\hline DEPTH & & & & & $\begin{array}{c}0.304^{* *} \\
(2.20)\end{array}$ & $\begin{array}{c}0.309 * * \\
(2.19)\end{array}$ \\
\hline Adj. $R^{2}$ & $\begin{array}{c}0.027^{* * *} \\
(3.85)\end{array}$ & $\begin{array}{c}0.089^{* * *} \\
(7.10)\end{array}$ & $\begin{array}{c}0.051^{* * *} \\
(4.12)\end{array}$ & $\begin{array}{c}0.128^{* * * *} \\
(5.06)\end{array}$ & $\begin{array}{c}0.279 * * * \\
(6.82)\end{array}$ & $\begin{array}{c}0.275^{* * *} \\
(6.72)\end{array}$ \\
\hline \multicolumn{7}{|c|}{ Panel B: Slope of CDS spreads measured by difference between 10-year and 1-year CDS spreads } \\
\hline Intercept & $\begin{array}{c}67.680^{* * *} \\
(10.11)\end{array}$ & $\begin{array}{c}56.586^{* * *} \\
(9.66)\end{array}$ & $\begin{array}{c}36.078^{* *} \\
(2.18)\end{array}$ & $\begin{array}{c}45.354^{* * *} \\
(6.20)\end{array}$ & $\begin{array}{c}59.659 * * * \\
(10.33)\end{array}$ & $\begin{array}{c}44.706^{* * *} \\
(8.31)\end{array}$ \\
\hline CSR & $\begin{array}{c}-1.157^{* * * *} \\
(-4.76)\end{array}$ & $\begin{array}{c}-0.892^{* * * *} \\
(-4.41)\end{array}$ & $\begin{array}{c}-1.078^{* * * *} \\
(-4.86)\end{array}$ & $\begin{array}{c}-0.879 * * * \\
(-4.81)\end{array}$ & $\begin{array}{c}-0.350 * * * \\
(-3.48)\end{array}$ & $\begin{array}{c}-0.356^{* * *} \\
(-3.68)\end{array}$ \\
\hline LEV & & $\begin{array}{c}0.386^{* * *} \\
(7.88)\end{array}$ & & & $\begin{array}{c}-0.041 \text { ** } \\
(-2.09)\end{array}$ & $\begin{array}{c}-0.039 * * \\
(-2.02)\end{array}$ \\
\hline IV & & & $\begin{array}{c}0.851^{* *} \\
(2.46)\end{array}$ & & $\begin{array}{c}-0.489^{* * *} \\
(-3.46)\end{array}$ & \\
\hline $\mathrm{HV}$ & & & & $\begin{array}{c}0.821^{* * *} \\
(4.60)\end{array}$ & & $\begin{array}{l}-0.052 \\
(-0.62)\end{array}$ \\
\hline CDS & & & & & $\begin{array}{c}0.213 \text { *** } \\
(6.87)\end{array}$ & $\begin{array}{c}0.201^{* * *} \\
(7.72)\end{array}$ \\
\hline ROA & & & & & $\begin{array}{l}-0.448 \\
(-1.46)\end{array}$ & $\begin{array}{l}-0.494 \\
(-1.60)\end{array}$ \\
\hline DEPTH & & & & & $\begin{array}{c}1.055^{*} \\
(1.89)\end{array}$ & $\begin{array}{c}1.074^{*} \\
(1.90)\end{array}$ \\
\hline Adj. $R^{2}$ & $\begin{array}{c}0.033^{* * *} \\
(4.10)\end{array}$ & $\begin{array}{c}0.116^{* * *} \\
(7.02)\end{array}$ & $\begin{array}{c}0.069^{* * *} \\
(4.10)\end{array}$ & $\begin{array}{c}0.159^{* * *} \\
(5.93)\end{array}$ & $\begin{array}{c}0.410 * * * \\
(8.48)\end{array}$ & $\begin{array}{c}0.404^{* * *} \\
(8.49)\end{array}$ \\
\hline
\end{tabular}

${ }^{* * *}, * *$, and $*$ indicate significance at the $1 \%, 5 \%$, and $10 \%$ levels, respectively.

Panel A shows the results of regressions when the five-year CDS spreads are used as the long-term CDS spreads. Regression I shows the result of a univariate regression of the slope of CDS spreads on CSR. The significantly negative coefficient of CSR indicates that the higher the CSR is, the lower is the slope of the CDS spreads. In other words, the differences between long- and short-term CDS spreads tend to be significantly lower when firms invest more in CSR activities. Meanwhile, according to the regression results of (Appendix A Table A1), CSR activities reduce the levels of the one-year CDS spreads (see panel A), meaning less short-term credit risk. Moreover, CSR activities also reduce the levels of the five-year CDS spreads (see panel B). Hence, firms that invest more in CSR activities reduce credit risk both in the long and short term. However, the effect of CSR activities is stronger for those with longer maturity, leading to a decrease in the CDS slope. The determinants of the CDS slope are leverage, option-implied volatility, and historical volatility, as proposed by Han and Zhou [18]; these are controlled for in regressions II, III, and IV, respectively. All three coefficients of leverage, implied volatility, and historical volatility are significantly positive. These findings are consistent with those of Han and Zhou [18]. Specifically, the coefficient of leverage indicates that if firms have higher leverage ratios, the difference between CDS with long- and short-term maturities is 
higher. Previous studies [24,49] indicate that leverage increases the CDS level (i.e., increases credit risk). Moreover, the results of Table A1 show that firms with higher leverage ratios increase CDS spreads in the long term more than in the short term. Regressions V and VI show the results when controlling for all cross-sectional effects such as leverage, volatility, return on assets, and CDS liquidity. We use option-implied volatility in regression $\mathrm{V}$ and historical volatility in regression VI to measure volatility. After controlling for all effects of firm-specific variables, the coefficients of historical volatility become insignificant. Furthermore, the adjusted $R^{2}$ in regression V (Adj. $R^{2}=0.279$ ), with option-implied volatility used as a proxy for volatility, is higher than that of regression VI (Adj. $R^{2}=0.275$ ), with historical volatility used as a proxy for volatility. Thus, option-implied volatility is likely to be an appropriate measure of volatility. After controlling for all variables, the coefficient of CSR remains negative and significant at the $1 \%$ level. This means that CSR negatively affects the CDS slope in a way that is not related to other cross-sectional effects. By adding all our control variables, we obtain another $20 \%$ of explanatory power compared with that of regressions II, III, and IV (Adjusted $\mathrm{R}^{2}$ increases to $28.0 \%$ )

We use the 10-year CDS spreads as the long-term CDS spreads and show the results in panel B. Regressions show the same results as those in panel A. The coefficient of CSR is still significantly negative at the $1 \%$ level after controlling for all firm-specific variables. Therefore, investing in CSR reduces CDS spreads in the long term more than it does in the short term (i.e., reducing credit risk more in the long term).

To extend our analysis, we examine the effects of the individual components of CSR on the CDS slope and show the results in Table 4. Specifically, we consider the following six dimensions: community (CSR_COM), diversity (CSR_DIV), employee relations (CSR_EMP), environment (CSR_ENV), human rights (CSR_HUM), and product characteristics (CSR_PRO), displayed in regressions I, II, III, IV, V, and VI respectively.

The difference between the five-year and one-year CDS spreads is used as the slope of CDS spreads in panel A. Regression I, II and III show significantly negative coefficients of CSR. This suggests that the three dimensions of CSR activities that negatively affect the CDS slope are community, diversity and employee relations. Meanwhile, according to the regression results in Table A1, the community, diversity and employee relations dimensions reduce the levels of the five-year CDS spreads (see in panel B), and they also reduce the levels of the one-year CDS spreads (see in panel A). In other words, firms with better community, diversity and employee relations scores are associated with lower CDS spreads both in the long term and short term. Furthermore, the difference between long- and short-term credit risks is lower with firms that have better levels of community, diversity and employee relations. The environment dimension reduces the CDS spreads both in the short and long terms (as shown in Table A1), but there is no significant difference between the short- and long-term CDS spreads, as shown in regression IV of Table 4. Interestingly, regressions VI and VII of Table A1 indicate that the human rights and product characteristics dimensions of CSR increase the level of the one- and five-year CDS spreads. In addition, the coefficients of CSR are significantly positive in regressions V and VI, as shown in Table 4. This means that the human rights and product characteristics dimensions of CSR activities increase the CDS spreads in the long term more than in the short term. Therefore, firms with higher scores on human rights and product characteristics are related to a higher CDS slope (i.e., increase the difference between the long- and short-term credit risk).

When using the difference between the 10-year and one-year CDS spreads as the measure of CDS slope, the results (as shown in panel B) are similar to panel A. The three dimensions of CSR activities, namely, community, diversity and employee relations, reduce CDS spreads more in the long term than in the short term. The CDS slope thus decreases when firms have higher levels of community, diversity and employee relations. By contrast, the human rights and product characteristics dimensions increase CDS spreads in the long term more than in the short term. Hence, the higher the human rights score or product characteristics score, the higher the CDS slope. The other dimensions do not affect the CDS slope. 
Table 4. Cross-sectional regressions of the slope of CDS spreads on CSR qualitative issue areas.

\begin{tabular}{|c|c|c|c|c|c|c|}
\hline Model & CSR_COM & CSR_DIV & CSR_EMP & CSR_ENV & CSR_HUM & CSR_PRO \\
\hline & (I) & (II) & (III) & (IV) & (V) & (VI) \\
\hline \multicolumn{7}{|c|}{ Panel A: Slope of CDS Spreads Measured by Difference between 5-Year and 1-Year CDS Spreads } \\
\hline Intercept & $\begin{array}{c}32.662^{* * *} \\
(11.88)\end{array}$ & $\begin{array}{c}33.606^{* * *} \\
(11.81)\end{array}$ & $\begin{array}{c}32.363^{* * *} \\
(11.96)\end{array}$ & $\begin{array}{c}32.728^{* * *} \\
(11.97)\end{array}$ & $\begin{array}{c}32.541 * * * \\
(11.96)\end{array}$ & $\begin{array}{c}33.156^{* * *} \\
(11.87)\end{array}$ \\
\hline CSR & $\begin{array}{c}-0.504^{* * *} \\
(-3.43)\end{array}$ & $\begin{array}{c}-0.656^{* * *} \\
(-5.06)\end{array}$ & $\begin{array}{c}-0.350 * * * \\
(-2.63)\end{array}$ & $\begin{array}{l}-0.136 \\
(-1.64)\end{array}$ & $\begin{array}{c}0.953^{* * *} \\
(3.08)\end{array}$ & $\begin{array}{c}0.743^{* * *} \\
(4.87)\end{array}$ \\
\hline LEV & $\begin{array}{l}-0.003 \\
(-0.28)\end{array}$ & $\begin{array}{l}-0.003 \\
(-0.35)\end{array}$ & $\begin{array}{l}-0.003 \\
(-0.26)\end{array}$ & $\begin{array}{l}-0.003 \\
(-0.24)\end{array}$ & $\begin{array}{l}-0.002 \\
(-0.14)\end{array}$ & $\begin{array}{l}0.001 \\
(0.10)\end{array}$ \\
\hline IV & $\begin{array}{c}-0.229 * * * \\
(-3.72)\end{array}$ & $\begin{array}{c}-0.234^{* * *} \\
(-3.70)\end{array}$ & $\begin{array}{c}-0.222 * * * \\
(-3.79)\end{array}$ & $\begin{array}{c}-0.232 * * * \\
(-3.77)\end{array}$ & $\begin{array}{c}-0.228^{* * * *} \\
(-3.73)\end{array}$ & $\begin{array}{c}-0.240 * * * \\
(-3.76)\end{array}$ \\
\hline CDS & $\begin{array}{c}0.072^{* * *} \\
(6.20)\end{array}$ & $\begin{array}{c}0.069 * * * \\
(6.17)\end{array}$ & $\begin{array}{c}0.071^{* * *} \\
(6.23)\end{array}$ & $\begin{array}{c}0.072 * * * \\
(6.13)\end{array}$ & $\begin{array}{c}0.072 * * * \\
(6.18)\end{array}$ & $\begin{array}{c}0.072 * * * \\
(6.22)\end{array}$ \\
\hline ROA & $\begin{array}{c}-0.359 * * \\
(-2.33)\end{array}$ & $\begin{array}{c}-0.375^{* *} \\
(-2.53)\end{array}$ & $\begin{array}{c}-0.327 * * \\
(-2.16)\end{array}$ & $\begin{array}{c}-0.352 * * \\
(-2.27)\end{array}$ & $\begin{array}{c}-0.332 * * \\
(-2.13)\end{array}$ & $\begin{array}{c}-0.365^{* *} \\
(-2.30)\end{array}$ \\
\hline DEPTH & $\begin{array}{l}0.217 \\
(1.62)\end{array}$ & $\begin{array}{c}0.266^{* *} \\
(2.09)\end{array}$ & $\begin{array}{l}0.202 \\
(1.54)\end{array}$ & $\begin{array}{l}0.212 \\
(1.60)\end{array}$ & $\begin{array}{l}0.214 \\
(1.61)\end{array}$ & $\begin{array}{c}0.237^{*} \\
(1.79)\end{array}$ \\
\hline Adj. $R^{2}$ & $\begin{array}{c}0.275^{* * *} \\
(7.87)\end{array}$ & $\begin{array}{c}0.283^{* * *} \\
(7.84)\end{array}$ & $\begin{array}{c}0.276^{* * *} \\
(7.87)\end{array}$ & $\begin{array}{c}0.274^{* * * *} \\
(8.00)\end{array}$ & $\begin{array}{c}0.275^{* * *} \\
(7.86)\end{array}$ & $\begin{array}{c}0.278^{* * *} \\
(7.88)\end{array}$ \\
\hline \multicolumn{7}{|c|}{ Panel B: Slope of CDS spreads measured by difference between 10-year and 1-year CDS spreads } \\
\hline Intercept & $\begin{array}{c}56.945^{* * *} \\
(10.83)\end{array}$ & $\begin{array}{c}58.668^{* * *} \\
(10.70)\end{array}$ & $\begin{array}{c}56.505^{* * *} \\
(10.86)\end{array}$ & $\begin{array}{c}57.057^{* * *} \\
(10.92)\end{array}$ & $\begin{array}{c}56.714^{* * *} \\
(10.86)\end{array}$ & $\begin{array}{c}57.702^{* * *} \\
(10.84)\end{array}$ \\
\hline CSR & $\begin{array}{c}-0.801 * * * \\
(-3.12)\end{array}$ & $\begin{array}{c}-1.147^{* * *} \\
(-4.53)\end{array}$ & $\begin{array}{c}-0.796^{* * *} \\
(-3.39)\end{array}$ & $\begin{array}{l}-0.234 \\
(-1.38)\end{array}$ & $\begin{array}{c}1.320 * * * \\
(2.91)\end{array}$ & $\begin{array}{c}1.358^{* * *} \\
(4.88)\end{array}$ \\
\hline LEV & $\begin{array}{l}-0.019 \\
(-0.92)\end{array}$ & $\begin{array}{l}-0.017 \\
(-0.90)\end{array}$ & $\begin{array}{l}-0.018 \\
(-0.87)\end{array}$ & $\begin{array}{l}-0.019 \\
(-0.89)\end{array}$ & $\begin{array}{l}-0.017 \\
(-0.85)\end{array}$ & $\begin{array}{l}-0.012 \\
(-0.58)\end{array}$ \\
\hline IV & $\begin{array}{c}-0.478^{* * *} \\
(-3.72)\end{array}$ & $\begin{array}{c}-0.491 * * * \\
(-3.73)\end{array}$ & $\begin{array}{c}-0.464^{* * *} \\
(-3.76)\end{array}$ & $\begin{array}{c}-0.482^{* * *} \\
(-3.77)\end{array}$ & $\begin{array}{c}-0.477^{* * * *} \\
(-3.73)\end{array}$ & $\begin{array}{c}-0.494^{* * *} \\
(-3.77)\end{array}$ \\
\hline CDS & $\begin{array}{c}0.204^{* * *} \\
(7.38)\end{array}$ & $\begin{array}{c}0.198^{* * *} \\
(7.41)\end{array}$ & $\begin{array}{c}0.202^{* * *} \\
(7.42)\end{array}$ & $\begin{array}{c}0.204^{* * *} \\
(7.34)\end{array}$ & $\begin{array}{c}0.205^{* * *} \\
(7.39)\end{array}$ & $\begin{array}{c}0.203^{* * *} \\
(7.40)\end{array}$ \\
\hline ROA & $\begin{array}{l}-0.373 \\
(-1.31)\end{array}$ & $\begin{array}{l}-0.369 \\
(-1.29)\end{array}$ & $\begin{array}{l}-0.313 \\
(-1.10)\end{array}$ & $\begin{array}{l}-0.362 \\
(-1.27)\end{array}$ & $\begin{array}{l}-0.334 \\
(-1.17)\end{array}$ & $\begin{array}{l}-0.381 \\
(-1.32)\end{array}$ \\
\hline DEPTH & $\begin{array}{c}0.835^{*} \\
(1.71)\end{array}$ & $\begin{array}{c}0.921 * \\
(1.94)\end{array}$ & $\begin{array}{c}0.808 * \\
(1.68)\end{array}$ & $\begin{array}{c}0.832 * \\
(1.72)\end{array}$ & $\begin{array}{c}0.838 * \\
(1.74)\end{array}$ & $\begin{array}{c}0.881 * \\
(1.81)\end{array}$ \\
\hline Adj. $R^{2}$ & $\begin{array}{c}0.391 \text { *** } \\
(8.92)\end{array}$ & $\begin{array}{c}0.397^{* * *} \\
(8.92)\end{array}$ & $\begin{array}{c}0.392 * * * \\
(8.80)\end{array}$ & $\begin{array}{c}0.391 * * * \\
(8.91)\end{array}$ & $\begin{array}{c}0.390^{* * *} \\
(8.82)\end{array}$ & $\begin{array}{c}0.393^{* * *} \\
(8.85)\end{array}$ \\
\hline
\end{tabular}

$* * * * *$, and ${ }^{*}$ indicate significance at the $1 \%, 5 \%$, and $10 \%$ levels, respectively.

\section{Conclusions}

This study has gone beyond previous studies by investigating whether CSR activities affect credit risk more strongly in the long or short term. We use the slope of CDS spreads, defined by the difference between long- and short-term CDS spreads, as proxy for the credit-term structure.

This study has found the following important results. Based on Fama-MacBeth regressions, our results indicate that after controlling for known cross-sectional effects of the CDS slope, the overall CSR score is negatively related to the CDS slope. In other words, firms with higher overall CSR score reduce the difference between long- and short-term credit risks, since CSR activities make credit risk go down in long term more than in short term. Both short- and long-term credit risks are reduced when investing in CSR activities, so firms consider CSR as an effective strategy rather than an expenditure. Indeed, CSR activities can create a positive image and a good relationship with firm stakeholders. This can increase firm value and decrease the uncertainty of future firm cash flow, thus reducing credit risk. Most CSR activities take a long time to realize the effect on firms' financing costs. Therefore, long-term borrowing cost is more sensitive to CSR activities. 
However, not all CSR activities reduce CDS slope. To gain further insight, we also examine the impact of each individual component of CSR on the CDS slope. The results reveal that community, diversity and employee relations are negatively related to the CDS slope. Specifically, CSR activities in these three areas reduce credit risks in both the short and long term. CSR activities directly related to primary stakeholders such as customers, communities, employees help firms create intangible assets, thereby increasing firm wealth and reducing credit risk [50]. By contrast, human rights and product characteristics are positively related to credit risks in both the short and long term. Especially, long-term credit risk is more sensitive to CSR activities, thus increasing the CDS slope. The effect of environment on the CDS slope is found to be insignificant. It is apparent that the negative effect of CSR on the CDS slope relates not only to one or two of the CSR dimensions. Instead, it is based on a broad set of CSR dimensions.

From this study, managers can be more confident to invest in CSR activities, especially in community, diversity and employee relations, because doing so can reduce credit risk. Moreover, the slope of term-structure CDS spreads is considered as a measure of firm's future health. A firm with flat slope of term-structure CDS spreads is expected to improve future credit wealth over the longer term [20]. Therefore, knowing the relationship between CSR-related activities and the slope of term-structure CDS spreads helps managers make appropriate strategic investments in CSR activities. In addition to managers, investors can also rely on this relationship to assess the firm's future credit wealth. For private firms or small firms with very little public information, investors have difficulty accessing accurate information to evaluate the firm. Hence, our study supports them in this regard. A firm that is increasingly engaged in CSR activities is likely to reduce the slope of credit term structure and improve credit health wealth.

Future work needs to address the following limitations of the present study to generalize the empirical implications. First, this study can be extended with international data. Cultural and religious differences may affect investor's perception of the effect of CSR-related activities. The findings of this study are limited to the United States. Hence, the analysis on the relationship between CSR-related activities and the term-structure of credit risk with cross-country data would be interesting. Second, we only analyzed a limited period. Thus, our findings might be true only for the period investigated. Given that the importance and interest of CSR activities are rapidly growing, the most recent data could provide more realistic implications.

Author Contributions: The authors contributed to this paper as follows. T.T.T.T.: software, formal analysis, investigation, writing-original draft preparation; J.K.: methodology, data curation, validation, writing-review and editing, supervision, project administration.

Funding: This work was supported by the 2019 Yeungnam University Research Grant.

Acknowledgments: The dataset used was obtained when Jungmu Kim was a research assistant professor at Korea Advanced Institute of Science and Technology (KAIST).

Conflicts of Interest: The authors declare no conflict of interest.

\section{Appendix A}

Table A1 presents the coefficients from cross-sectional Fama-MacBeth regressions. The dependent variable is the long-term CDS spread, defined by the five-year CDS spread (in Panel B) or ten-year CDS spread (in panel C), or the short-term CDS spread, defined by the one-year CDS spread (in Panel A). The independent variables include CSR score (CSR), leverage ratio (LEV), option-implied volatility (IV), return on assets (ROA), and CDS liquidity (DEPTH). In model I, the overall CSR score is used as the CSR variable. In models II, III, IV, V, VI, and VII, the CSR variables are CSR scores for areas of the qualitative issue, namely, community, diversity, employee relations, environment, human rights, and product characteristics, respectively. The sample period is from January 2001 to December 2013. The values in parentheses below each coefficient are Newey-West t-statistics. 
Table A1. Cross-sectional regressions of the levels of CDS spreads on overall CSR scores and individual components of CSR.

\begin{tabular}{|c|c|c|c|c|c|c|c|}
\hline Model & CSR & CSR_COM & CSR_DIV & CSR_EMP & CSR_ENV & CSR_HUM & CSR_PRO \\
\hline & (I) & (II) & (III) & (IV) & (V) & (VI) & (VII) \\
\hline \multicolumn{8}{|c|}{ Panel A: 1-Year CDS Spreads } \\
\hline Intercept & $\begin{array}{c}-71.379 * * * \\
(-3.33)\end{array}$ & $\begin{array}{c}-72.869 * * * \\
(-3.42)\end{array}$ & $\begin{array}{c}-68.811^{* * *} \\
(-3.31)\end{array}$ & $\begin{array}{c}-72.658^{* * *} \\
(-3.37)\end{array}$ & $\begin{array}{c}-71.862 * * * \\
(-3.36)\end{array}$ & $\begin{array}{c}-74.359 * * * \\
(-3.48)\end{array}$ & $\begin{array}{c}-72.311^{* * *} \\
(-3.43)\end{array}$ \\
\hline CSR & $\begin{array}{c}-1.081 \text { *** } \\
(-5.24)\end{array}$ & $\begin{array}{c}-2.227^{* * *} \\
(-5.07)\end{array}$ & $\begin{array}{c}-2.768 * * * \\
(-6.77)\end{array}$ & $\begin{array}{c}-2.722 * * * \\
(-4.56)\end{array}$ & $\begin{array}{l}-0.837 \\
(-1.51)\end{array}$ & $\begin{array}{c}3.426^{* *} \\
(2.18)\end{array}$ & $\begin{array}{l}1.052 \\
(1.42)\end{array}$ \\
\hline LEV & $\begin{array}{c}0.853 * * * \\
(7.86)\end{array}$ & $\begin{array}{c}0.873^{* * *} \\
(8.05)\end{array}$ & $\begin{array}{c}0.851 * * * \\
(7.40)\end{array}$ & $\begin{array}{c}0.875^{* * *} \\
(8.04)\end{array}$ & $\begin{array}{c}0.873^{* * *} \\
(8.08)\end{array}$ & $\begin{array}{c}0.888^{* * *} \\
(8.36)\end{array}$ & $\begin{array}{c}0.893^{* * *} \\
(8.58)\end{array}$ \\
\hline IV & $\begin{array}{c}3.347^{* * *} \\
(5.92)\end{array}$ & $\begin{array}{c}3.361^{* * *} \\
(5.98)\end{array}$ & $\begin{array}{c}3.299 * * * \\
(5.95)\end{array}$ & $\begin{array}{c}3.350 * * * \\
(5.93)\end{array}$ & $\begin{array}{c}3.348^{* * *} \\
(5.95)\end{array}$ & $\begin{array}{c}3.386^{* * *} \\
(6.00)\end{array}$ & $\begin{array}{c}3.338^{* * *} \\
(6.00)\end{array}$ \\
\hline $\mathrm{ROA}$ & $\begin{array}{c}-5.904^{* * *} \\
(-7.16)\end{array}$ & $\begin{array}{c}-6.052^{* * *} \\
(-7.68)\end{array}$ & $\begin{array}{c}-6.025^{* * *} \\
(-6.97)\end{array}$ & $\begin{array}{c}-6.071^{* * * *} \\
(-7.39)\end{array}$ & $\begin{array}{c}-6.030^{* * * *} \\
(-7.49)\end{array}$ & $\begin{array}{c}-6.019 * * * \\
(-8.32)\end{array}$ & $\begin{array}{c}-6.120 * * * \\
(-8.04)\end{array}$ \\
\hline DEPTH & $\begin{array}{c}-3.473^{* * *} \\
(-4.70)\end{array}$ & $\begin{array}{c}-3.492^{* * *} \\
(-4.64)\end{array}$ & $\begin{array}{c}-3.255^{* * *} \\
(-4.34)\end{array}$ & $\begin{array}{c}-3.561^{* * * *} \\
(-4.76)\end{array}$ & $\begin{array}{c}-3.555^{* * * *} \\
(-4.71)\end{array}$ & $\begin{array}{c}-3.523 * * * \\
(-4.63)\end{array}$ & $\begin{array}{c}-3.575^{* * *} \\
(-4.70)\end{array}$ \\
\hline $\operatorname{Adj} . R^{2}$ & $\begin{array}{c}0.460 \text { *** } \\
(21.80)\end{array}$ & $\begin{array}{c}0.455^{* * *} \\
(22.17)\end{array}$ & $\begin{array}{c}0.463 \\
(22.88)\end{array}$ & $\begin{array}{c}0.458^{* * *} \\
(21.94)\end{array}$ & $\begin{array}{c}0.457^{* * *} \\
(21.98)\end{array}$ & $\begin{array}{c}0.458^{* * *} \\
(23.00)\end{array}$ & $\begin{array}{c}0.457^{* * *} \\
(22.55)\end{array}$ \\
\hline \multicolumn{8}{|c|}{ Panel B: 5-year CDS levels } \\
\hline Intercept & $\begin{array}{l}-52.09 \\
(-1.59)\end{array}$ & $\begin{array}{c}-55.812^{*} \\
(-1.74)\end{array}$ & $\begin{array}{c}-46.612 \\
(-1.51)\end{array}$ & $\begin{array}{c}-55.999 * \\
(-1.70)\end{array}$ & $\begin{array}{c}-53.994 * \\
(-1.66)\end{array}$ & $\begin{array}{c}-58.789 * \\
(-1.83)\end{array}$ & $\begin{array}{c}-54.862 * \\
(-1.75)\end{array}$ \\
\hline CSR & $\begin{array}{c}-2.163 * * * \\
(-5.23)\end{array}$ & $\begin{array}{c}-5.611^{* * * *} \\
(-4.58)\end{array}$ & $\begin{array}{c}-6.349^{* * * *} \\
(-5.35)\end{array}$ & $\begin{array}{c}-5.028^{* * * *} \\
(-6.83)\end{array}$ & $\begin{array}{c}-2.024 \text { * } \\
(-1.78)\end{array}$ & $\begin{array}{c}7.143^{* * *} \\
(4.03)\end{array}$ & $\begin{array}{c}4.206^{* * *} \\
(5.73)\end{array}$ \\
\hline LEV & $\begin{array}{c}1.469 * * * \\
(7.04)\end{array}$ & $\begin{array}{c}1.499 * * * \\
(7.23)\end{array}$ & $\begin{array}{c}1.471^{* * *} \\
(6.92)\end{array}$ & $\begin{array}{c}1.505^{* * *} \\
(7.19)\end{array}$ & $\begin{array}{c}1.509 * * * \\
(7.23)\end{array}$ & $\begin{array}{c}1.534^{* * *} \\
(7.38)\end{array}$ & $\begin{array}{c}1.547^{* * *} \\
(7.57)\end{array}$ \\
\hline IV & $\begin{array}{c}4.157^{* * *} \\
(5.03)\end{array}$ & $\begin{array}{c}4.208^{* * *} \\
(5.13)\end{array}$ & $\begin{array}{c}4.027^{* * *} \\
(5.08)\end{array}$ & $\begin{array}{c}4.202 * * * \\
(5.06)\end{array}$ & $\begin{array}{c}4.184^{* * *} \\
(5.06)\end{array}$ & $\begin{array}{c}4.250 * * * \\
(5.14)\end{array}$ & $\begin{array}{c}4.156^{* * *} \\
(5.14)\end{array}$ \\
\hline $\mathrm{ROA}$ & $\begin{array}{c}-9.213^{* * *} \\
(-12.43)\end{array}$ & $\begin{array}{c}-9.546^{* * *} \\
(-13.81)\end{array}$ & $\begin{array}{c}-9.363^{* * *} \\
(-11.73)\end{array}$ & $\begin{array}{c}-9.476^{* * *} \\
(-13.58)\end{array}$ & $\begin{array}{c}-9.464^{* * *} \\
(-13.43)\end{array}$ & $\begin{array}{c}-9.583 * * * \\
(-15.54)\end{array}$ & $\begin{array}{c}-9.700 * * * \\
(-14.86)\end{array}$ \\
\hline DEPTH & $\begin{array}{c}-4.480 * * * \\
(-5.08)\end{array}$ & $\begin{array}{c}-4.488^{* * *} \\
(-5.06)\end{array}$ & $\begin{array}{c}-3.970 * * * \\
(-4.33)\end{array}$ & $\begin{array}{c}-4.723 * * * \\
(-5.33)\end{array}$ & $\begin{array}{c}-4.680 * * * \\
(-5.10)\end{array}$ & $\begin{array}{c}-4.683 * * * \\
(-5.06)\end{array}$ & $\begin{array}{c}-4.585^{* * *} \\
(-4.98)\end{array}$ \\
\hline Adj. $R^{2}$ & $\begin{array}{c}0.482^{* * *} \\
(34.60)\end{array}$ & $\begin{array}{c}0.472 * * * \\
(36.54)\end{array}$ & $\begin{array}{c}0.490 * * * \\
(39.41)\end{array}$ & $\begin{array}{c}0.476^{* * *} \\
(35.76)\end{array}$ & $\begin{array}{c}0.474^{* * *} \\
(36.01)\end{array}$ & $\begin{array}{c}0.472 * * * \\
(40.89)\end{array}$ & $\begin{array}{c}0.472 * * * \\
(38.99)\end{array}$ \\
\hline \multicolumn{8}{|c|}{ Panel C: 10-year CDS levels } \\
\hline Intercept & $\begin{array}{c}-45.849 \\
(-1.28)\end{array}$ & $\begin{array}{c}-50.037 \\
(-1.42)\end{array}$ & $\begin{array}{c}-39.135 \\
(-1.17)\end{array}$ & $\begin{array}{c}-50.389 \\
(-1.40)\end{array}$ & $\begin{array}{c}-48.284 \\
(-1.36)\end{array}$ & $\begin{array}{c}-53.418 \\
(-1.52)\end{array}$ & $\begin{array}{c}-48.791 \\
(-1.43)\end{array}$ \\
\hline CSR & $\begin{array}{c}-2.420^{* * *} \\
(-5.25)\end{array}$ & $\begin{array}{c}-6.338^{* * * *} \\
(-4.52)\end{array}$ & $\begin{array}{c}-7.175^{* * * *} \\
(-5.32)\end{array}$ & $\begin{array}{c}-5.744^{* * * *} \\
(-6.80)\end{array}$ & $\begin{array}{c}-2.258^{*} \\
(-1.88)\end{array}$ & $\begin{array}{c}8.125^{* * *} \\
(4.35)\end{array}$ & $\begin{array}{c}5.142 * * * \\
(6.10)\end{array}$ \\
\hline LEV & $\begin{array}{c}1.602 * * * \\
(7.07)\end{array}$ & $\begin{array}{c}1.635^{* * *} \\
(7.28)\end{array}$ & $\begin{array}{c}1.606^{* * *} \\
(6.98)\end{array}$ & $\begin{array}{c}1.639^{* * * *} \\
(7.23)\end{array}$ & $\begin{array}{c}1.647^{* * *} \\
(7.27)\end{array}$ & $\begin{array}{c}1.674^{* * *} \\
(7.43)\end{array}$ & $\begin{array}{c}1.690 * * * \\
(7.62)\end{array}$ \\
\hline IV & $\begin{array}{c}4.555^{* * *} \\
(5.01)\end{array}$ & $\begin{array}{c}4.614^{* * *} \\
(5.11)\end{array}$ & $\begin{array}{c}4.394^{* * *} \\
(5.07)\end{array}$ & $\begin{array}{c}4.613^{* * *} \\
(5.04)\end{array}$ & $\begin{array}{c}4.593^{* * *} \\
(5.04)\end{array}$ & $\begin{array}{c}4.663 * * * \\
(5.12)\end{array}$ & $\begin{array}{c}4.553^{* * *} \\
(5.13)\end{array}$ \\
\hline $\mathrm{ROA}$ & $\begin{array}{c}-9.933^{* * *} \\
(-12.16)\end{array}$ & $\begin{array}{c}-10.317^{* * *} \\
(-13.50)\end{array}$ & $\begin{array}{c}-10.086 \text { *** } \\
(-11.46)\end{array}$ & $\begin{array}{c}-10.197^{* * *} \\
(-13.61)\end{array}$ & $\begin{array}{c}-10.232 * * * \\
(-13.13)\end{array}$ & $\begin{array}{c}-10.340^{* * *} \\
(-15.54)\end{array}$ & $\begin{array}{c}-10.479 * * * \\
(-14.61)\end{array}$ \\
\hline DEPTH & $\begin{array}{c}-3.881^{* * *} \\
(-6.39)\end{array}$ & $\begin{array}{c}-3.878^{* * *} \\
(-6.38)\end{array}$ & $\begin{array}{c}-3.302 * * * \\
(-4.88)\end{array}$ & $\begin{array}{c}-4.142 * * * \\
(-7.09)\end{array}$ & $\begin{array}{c}-4.095^{* * *} \\
(-6.51)\end{array}$ & $\begin{array}{c}-4.091 \text { *** } \\
(-6.58)\end{array}$ & $\begin{array}{c}-3.963 * * * \\
(-6.28)\end{array}$ \\
\hline Adj. $R^{2}$ & $\begin{array}{c}0.469 * * * \\
(31.12)\end{array}$ & $\begin{array}{c}0.459 * * * \\
(31.89)\end{array}$ & $\begin{array}{c}0.478^{* * *} \\
(34.83)\end{array}$ & $\begin{array}{c}0.464^{* * *} \\
(31.58)\end{array}$ & $\begin{array}{c}0.460 * * * \\
(31.41)\end{array}$ & $\begin{array}{c}0.459 * * * \\
(34.09)\end{array}$ & $\begin{array}{c}0.459 * * * \\
(33.20)\end{array}$ \\
\hline
\end{tabular}

$* * *, * *$, and * indicate significance at the $1 \%, 5 \%$, and $10 \%$ levels, respectively.

\section{References}

1. Brown, T.J.; Dacin, P.A. The Company and the Product: Corporate Associations and Consumer Product Responses. J. Mark. 1997, 61, 68-84. [CrossRef]

2. Sen, S.; Bhattacharya, C.B. Does Doing Good Always Lead to Doing Better? Consumer Reactions to Corporate Social Responsibility. J. Mark. Res. 2001, 38, 225-243. [CrossRef] 
3. Jo, H.; Harjoto, M.A. Corporate Governance and Firm Value: The Impact of Corporate Social Responsibility. J. Bus. Ethics 2011, 103, 351-383. [CrossRef]

4. Mahoney, L.; Roberts, R.W. Corporate social performance, financial performance and institutional ownership in Canadian firms. Account. Forum 2007, 31, 233-253. [CrossRef]

5. Perrini, F.; Russo, A.; Tencati, A.; Vurro, C. Deconstructing the Relationship Between Corporate Social and Financial Performance. J. Bus. Ethics 2011, 102, 59-76. [CrossRef]

6. Galbreath, J.; Shum, P. Do customer satisfaction and reputation mediate the CSR-FP link? Evidence from Australia. Aust. J. Manag. 2012, 37, 211-229. [CrossRef]

7. Servaes, H.; Tamayo, A. The Impact of Corporate Social Responsibility on Firm Value: The Role of Customer Awareness. Manag. Sci. 2013, 59, 1045-1061. [CrossRef]

8. Lee, D.D.; Faff, R.W. Corporate sustainability performance and idiosyncratic risk: A global perspective. Financ. Rev. 2009, 44, 213-237. [CrossRef]

9. Albuquerque, R.; Koskinen, Y.; Zhang, C. Corporate Social Responsibility and Firm Risk: Theory and Empirical Evidence. Manag. Sci. 2018. [CrossRef]

10. Dhaliwal, D.S.; Li, O.Z.; Tsang, A.; Yang, Y.G. Voluntary Nonfinancial Disclosure and the Cost of Equity Capital: The Initiation of Corporate Social Responsibility Reporting. Account. Rev. 2011, 86, 59-100. [CrossRef]

11. El Ghoul, S.; Guedhami, O.; Kwok, C.C.Y.; Mishra, D.R. Does corporate social responsibility affect the cost of capital? J. Bank. Financ. 2011, 35, 2388-2406. [CrossRef]

12. Goss, A.; Roberts, G.S. The impact of corporate social responsibility on the cost of bank loans. J. Bank. Financ. 2011, 35, 1794-1810. [CrossRef]

13. Sun, W.; Cui, K. Linking corporate social responsibility to firm default risk. Eur. Manag. J. 2014, 32, $275-287$. [CrossRef]

14. Attig, N.; El Ghoul, S.; Guedhami, O.; Suh, J. Corporate Social Responsibility and Credit Ratings. J. Bus. Ethics 2013, 117, 679-694. [CrossRef]

15. Oikonomou, I.; Brooks, C.; Pavelin, S. The effects of corporate social performance on the cost of corporate debt and credit ratings. Financ. Rev. 2014, 49, 49-75. [CrossRef]

16. Jiraporn, P.; Jiraporn, N.; Boeprasert, A.; Chang, K. Does corporate social responsibility (CSR) improve credit ratings? Evidence from geographic identification. Financ. Manag. 2014, 43, 505-531. [CrossRef]

17. Ericsson, J.; Jacobs, K.; Oviedo, R. The Determinants of Credit Default Swap Premia. J. Financ. Quant. Anal. 2009, 44, 109-132. [CrossRef]

18. Han, B.; Zhou, Y. Understanding the term structure of credit default swap spreads. J. Empir. Financ. 2015, 31, 18-35. [CrossRef]

19. Barth, F.; Hübel, B.; Scholz, H. ESG and Corporate Credit Spreads: Evidence from Europe. 2019. Available online: https://ssrn.com/abstract=3179468 (accessed on 28 June 2019).

20. Han, B.; Subrahmanyam, A.; Zhou, Y. The term structure of credit spreads, firm fundamentals, and expected stock returns. J. Financ. Econ. 2017, 124, 147-171. [CrossRef]

21. Fama, E.F.; MacBeth, J.D. Risk, Return, and Equilibrium: Empirical Tests. J. Political Econ. 1973, 81, $607-636$. [CrossRef]

22. Merton, R.C. On the pricing of corporate debt: The risk structure of interest rates*. J. Financ. 1974, 29, 449-470.

23. Collin-Dufresne, P.; Goldstein, R.S.; Martin, J.S. The determinants of credit spread changes. J. Financ. 2001, 56, 2177-2207. [CrossRef]

24. Galil, K.; Shapir, O.M.; Amiram, D.; Ben-Zion, U. The determinants of CDS spreads. J. Bank. Financ. 2014, 41, 271-282. [CrossRef]

25. Du, D.; Elkamhi, R.; Ericsson, J. Time-Varying Asset Volatility and the Credit Spread Puzzle. J. Financ. 2019, 74, 1841-1885. [CrossRef]

26. Luo, X.; Bhattacharya, C.B. Corporate Social Responsibility, Customer Satisfaction, and Market Value. J. Mark. 2006, 70, 1-18. [CrossRef]

27. Pivato, S.; Misani, N.; Tencati, A. The impact of corporate social responsibility on consumer trust: The case of organic food. Bus. Ethics A Eur. Rev. 2008, 17, 3-12. [CrossRef]

28. Bhattacharya, C.B.; Sen, S. Consumer-company identification: A framework for understanding consumers' relationships with companies. J. Mark. 2003, 67, 76-88. [CrossRef] 
29. Bhattacharya, C.B.; Sen, S. Doing Better at Doing Good: When, Why, and How Consumers Respond to Corporate Social Initiatives. Calif. Manag. Rev. 2004, 47, 9-24. [CrossRef]

30. Lichtenstein, D.R.; Drumwright, M.E.; Braig, B.M. The Effect of Corporate Social Responsibility on Customer Donations to Corporate-Supported Nonprofits. J. Mark. 2004, 68, 16-32. [CrossRef]

31. Rettab, B.; Brik, A.B.; Mellahi, K. A Study of Management Perceptions of the Impact of Corporate Social Responsibility on Organisational Performance in Emerging Economies: The Case of Dubai. J. Bus. Ethics 2009, 89, 371-390. [CrossRef]

32. Alafi, K.; Hasoneh, A.B. Corporate social responsibility associated with customer satisfaction and financial performance a case study with Housing Banks in Jordan. Int. J. Humanit. Soc. Sci. 2012, 2, 102-115.

33. Campbell, J.Y.; Shiller, R.J. The dividend-price ratio and expectations of future dividends and discount factors. Rev. Financ. Stud. 1988, 1, 195-228. [CrossRef]

34. Schnietz, K.E.; Epstein, M.J. Exploring the financial value of a reputation for corporate social responsibility during a crisis. Corp. Reput. Rev. 2005, 7, 327-345. [CrossRef]

35. Godfrey, P.C.; Merrill, C.B.; Hansen, J.M. The relationship between corporate social responsibility and shareholder value: An empirical test of the risk management hypothesis. Strateg. Manag. J. 2009, 30, 425-445. [CrossRef]

36. Turban, D.B.; Greening, D.W. Corporate social performance and organizational attractiveness to prospective employees. Acad. Manag. J. 1997, 40, 658-672.

37. Greening, D.W.; Turban, D.B. Corporate social performance as a competitive advantage in attracting a quality workforce. Bus. Soc. 2000, 39, 254-280. [CrossRef]

38. Barney, J. Firm resources and sustained competitive advantage. J. Manag. 1991, 17, 99-120. [CrossRef]

39. Surroca, J.; Tribó, J.A.; Waddock, S. Corporate responsibility and financial performance: The role of intangible resources. Strateg. Manag. J. 2010, 31, 463-490. [CrossRef]

40. Jo, H.; Na, H. Does CSR Reduce Firm Risk? Evidence from Controversial Industry Sectors. J. Bus. Ethics 2012, 110, 441-456. [CrossRef]

41. Bouslah, K.; Kryzanowski, L.; M'Zali, B. The impact of the dimensions of social performance on firm risk. J. Bank. Financ. 2013, 37, 1258-1273. [CrossRef]

42. Chang, T.-C.; Yan, Y.-C.; Chou, L.-C. Is default probability associated with corporate social responsibility? Asia-Pac. J. Account. Econ. 2013, 20, 457-472. [CrossRef]

43. Black, F.; Scholes, M. The pricing of options and corporate liabilities. J. Polit. Econ. 1973, 81, 637-654. [CrossRef]

44. Friewald, N.; Wagner, C.; Zechner, J. The Cross-Section of Credit Risk Premia and Equity Returns. J. Financ. 2014, 69, 2419-2469. [CrossRef]

45. Kim, Y.; Li, H.; Li, S. Corporate social responsibility and stock price crash risk. J. Bank. Financ. 2014, 43, 1-13. [CrossRef]

46. Qiu, J.; Yu, F. Endogenous liquidity in credit derivatives. J. Financ. Econ. 2012, 103, 611-631. [CrossRef]

47. Lee, J.; Naranjo, A.; Sirmans, S. The Exodus from Sovereign Risk: Sovereign Ceiling Violations in Credit Default Swap Markets. 2013. Available online: https://ssrn.com/abstract=2237913 (accessed on 28 June 2019).

48. Newey, W.K.; West, K.D. A simple, positive semi-definite, heteroskedasticity and autocorrelation consistent covariance matrix. Econometrica 1987, 55, 703-708. [CrossRef]

49. Zhang, B.Y.; Zhou, H.; Zhu, H. Explaining Credit Default Swap Spreads with the Equity Volatility and Jump Risks of Individual Firms. Rev. Financ. Stud. 2009, 22, 5099-5131. [CrossRef]

50. Hillman, A.J.; Keim, G.D. Shareholder value, stakeholder management, and social issues: what's the bottom line? Strateg. Manag. J. 2001, 22, 125-139. [CrossRef]

(C) 2019 by the authors. Licensee MDPI, Basel, Switzerland. This article is an open access article distributed under the terms and conditions of the Creative Commons Attribution (CC BY) license (http://creativecommons.org/licenses/by/4.0/). 